Konya Mühendislik Bilimleri Dergisi, c. 9, s. 4, 1051-1062, 2021

Konya Journal of Engineering Sciences, v. 9, n. 4, 1051-1062, 2021

ISSN: 2667-8055 (Elektronik)

DOI: 10.36306/konjes.998716

\title{
RESEARCHING THE EFFECTS OF SOCIO-DEMOGRAPHIC VARIABLES ON THE ETHICAL ATTITUDE LEVEL OF GEOMATICS ENGINEERING STUDENTS
}

\author{
1Şaban İNAM ${ }^{(\mathbb{D})}$, ${ }^{2}$ Halil Burak AKDENIZ \\ ${ }^{1}$ sinam@ktun.edu.tr, 2hbakdeniz@ktun.edu.tr \\ Konya Technical University, Faculty of Engineering and Natural Sciences, Department of Geomatics Engineering, \\ Konya, TURKEY
}

(Geliş/Received: 21.09.2021; Kabul/Accepted in Revised Form: 04.11.2021)

\begin{abstract}
The importance of ethical behaviour has increased gradually in today's business life, and people who are unaware of ethical rules and requirements are not preferred by employers, customers and employees has been observed. For this purpose, the course of engineering ethics (professional ethics) was put into the syllabus as compulsory for geomatics engineering students undergraduate and graduate education programs in Turkey by Higher Education Council in order to teach ethic principals and professional responsibility and to gain the ability to query professional dilemmas. This study was planned to examine the engineering ethics attitude levels of geomatics engineering students taking the professional ethics course, and to determine the effect of socio-demographic variables on the attitude levels of engineering ethics. The sample of the study consisted of 224 students who voluntarily participated in the survey. In the research, Engineering Ethics Scale and Socio-Demographic Data Collection Form consisting of 21 items were used. In the analysis of the data, number / percentage analysis, Shapiro Wilk, Mann Whitney U, Kruskal Wallis and Mann Whitney U tests with Bonferroni correction were used. Significance level was accepted as 0.05 in statistical analysis. In the study, it was determined that the students who took the professional ethics course had high engineering ethics attitude levels, and there was a statistically significant relationship between the variables of gender, age and socio-economic status and engineering ethics attitude levels.
\end{abstract}

Key Words: Engineering ethics, Socio-demographic variables, Engineering education, Ethical values

\section{Sosyo-Demografik Değişkenlerin Harita Mühendisliği Öğrencilerinin Etik Tutum Düzeyine Etkilerinin Araştırılması}

ÖZ: Günümüz iş hayatında etik davranışların önemi giderek artmış; etik kurallar ve gerekliliklerin bilincinde olmayan kişilerin işverenler, müşteriler ve çalışanlar tarafından tercih edilmediği anlaşılmaktadır. Bu amaçla, Yükseköğretim Kurumu tarafından Türkiye'de harita mühendisliği lisans ve lisansüstü eğitim programlarındaki öğrencilere mühendislik etiği (mesleki etik) dersi zorunlu okutularak, öğrencinin "etik ilkeleri, mesleki sorumluluğu öğrenmesi ve mesleki ikilemleri sorgulaması yeteneğini kazanması" hedeflenmiştir. Bu çalışma, mesleki etik dersini alan harita mühendisliği öğrencilerinin mühendislik etiği tutum düzeylerini incelemek, sosyo-demografik değişkenlerin mühendislik etiği tutum düzeylerine olan etkisini belirlemek amacıyla planlanmıştır. Çalışmanın örneklemini, ankete gönüllü katılan 224 öğrenci oluşturmuştur. Araştırmada, 21 maddeden oluşan Mühendislik Etiği Ölçeği ve SosyoDemografik Veri Toplama Formu kullanılmıştır. Verilerin analizinde; sayı/yüzde analizi, Shapiro Wilk, Mann Whitney U, Kruskal Wallis ve Bonferroni düzeltmeli Mann Whitney U testlerinden yararlanılmıştır. İstatistiksel analizlerde anlamlılık düzeyi 0.05 olarak kabul edilmiştir. Araştırmada, mesleki etik dersini alan öğrencilerin mühendislik etiği tutum düzeylerinin yüksek olduğu, cinsiyet, yaş ve sosyo-ekonomik 
durum değişkenleri ile mühendislik etiği tutum düzeyleri arasında istatistiki olarak anlamlı bir ilişki olduğu tespit edilmiştir.

Anahtar Kelimeler: Mühendislik etiği, Sosyo-demografik değişkenler, Mühendislik eğitimi, Etik değerler

\section{INTRODUCTION}

Ethics is a concept that takes place in all areas of social life and is used with care from our daily work to the highest levels of management. The concept of ethics, appearing at every stage of social life, is a compass for the individual and indicates the directions of the road or route; however, it leaves the issue of which way to go to the interests and discretion of individuals (İnam and Akdeniz, 2020). Ethics with a different approach, was developed for the purpose of theorizing and is a relationship between thought and action. The information transferred to the individual through ethics is not only theoretical, but also 'action-generating' information that is transferred to practice through behaviours and exists only in practice (Pieper, 1999).

The professional ethical codes that direct the behaviours in working life are professional principles that direct members of a particular profession, force them to act within certain rules when necessary and limit their personal tendencies, exclude inadequate or unprincipled members from the profession, regulate professional competition and protect their professional ideals (Milli Eğitim Bakanlığı, 2006). One of the most important features of professional ethics, which takes its source from universal ethical values, is that it emphasizes that individuals who perform the same profession in the international arena should act in accordance with these codes of conduct. The emergence of the ethical codes of a profession and their adoption by those who do that profession is a fundamental step towards the professionalization of that profession, the recognition of the autonomy of the profession and the profession's privilege of self-control (Colby and Sullivan, 2008). International professional organizations and some national unions have created their own codes of professional ethics within the framework of universal professional ethical values. One of these codes of professional ethics is engineering ethics. The first written principles of engineering ethics in historical process, were put forward by the American Society for Engineering Education (ASEE) in 1912 and were accepted by other professional chambers over the years (Griggs, 1997). On October 5, 1977, "Code of Ethics for Engineers" was announced by the National Society of Professional Engineers. As in all the world, identified the principles of engineering ethics in Turkey, it has been decisive in the development of chambers, and Union of Chambers of Turkish Engineers and Architects (UCTEA) set forth in the principle foundation engineering ethics has released the 'Professional Conduct Policies' in 2003. With UCTEA's revealing the principal foundations of engineering ethics, all affiliated chamber organizations representing different engineering fields have determined their own situations accordingly (Taluğ et al., 2015).

Human beings, who are not a moral being by their creation, must be educated and educated in behaviour. Lack of knowledge, which is among the reasons for individuals to resort to unethical means, can only be eliminated with well-organized educational studies (İnayet, 2002). There is a mutual interaction between the acquisition of ethical values and education. Individuals should be educated in order to understand engineering ethics correctly and to have a right say in discussions on ethics (Eroğlu et al., 2019). Technological developments and social events have revealed that ethics in engineering education should be handled more consciously. As a requirement of this, non-governmental organizations at national and international level:

- Suggestion of the Chamber of Survey and Cadastre Engineers (CSCE) affiliated to UCTEA,

- The views of the International Federation of Surveyors (FIG) that "The ethical values and behaviours that those who carry out the cartography profession should have should be given through formal education and vocational training" (FIG, 2002),

- US Engineering and Technology Equivalency Agency's EC2000 Criteria for Engineering Programs (ABET, 2005),

- Accreditation and evaluation studies to be carried out according to contribute to enhancing the 
quality of engineering education of the Association for Evaluation and Accreditation of Engineers Progragrams (MÜDEK),

- Accreditation studies to be carried out according to the equivalence criteria of the European Engineering Programs and Graduates Equivalency Project EUR-ACE. (Deniz et al., 2005).

in line with, "the necessity of ethics education" was the subject of their studies. With the belief that this ethics education is necessary, the engineering/professional ethics course curriculum was created and added to the Geomatics Engineering department curriculum of universities in Turkey. Engineering ethics course should be ensured that students who will start their professional life after university will gain "understanding of universal ethical rules and values, learning the principles of engineering ethics and professional responsibility, and the ability to question professional dilemmas". As a result of the this course; individuals will be evolved who have developed the ability of free and scientific thinking and evaluation, have reached the maturity to make their decisions without any influence, do not see themselves outside of society, question the events, are sceptical in the sense of science and are free from prejudices, are aware of their responsibilities and can express themselves (Gençoğlu, 2008). In this education process, there is a need for "education programs that aim at social expectations and periodic recycling determinations of these programs" that are in an approach that takes into account the values such as customs, traditions and family education that the individual has acquired from the past.

Studies have been conducted to determine the "effect of socio-demographic variables on the ethical attitude and behaviour of the student", and it has been determined that socio-demographic variables affect the ethical attitude and behaviour of the student (Ruegger and King, 1992; Galbraith and Stephenson, 1993; Ameen et al., 1996; Dawson, 1997; Fritzche, 1997; Knotts et al., 2000, Adkins and Radtke, 2004; Kutlu, 2008; Alkan, 2015; Akkaya, 2016; Küçük et al., 2017; Aykan et al., 2019). Although professional ethics is an important concept for professions in the field of science, in the literature review, it was seen that although many studies have been done in the field of social sciences and health sciences, there are not enough studies in the field of science. For this purpose, the engineering ethics attitude levels of the students of the geomatics engineering department who took the professional ethics course were determined, whether these levels differ according to socio-demographic variables was tried to determine.

\section{MATERIAL AND METHODS}

\subsection{Purpose of the Study}

The aim of this study is to examine the engineering ethics attitude levels of the students of the geomatics engineering department who take the professional ethics course and to determine the effect of socio-demographic variables on the engineering ethics attitude levels.

\subsection{Study Design and Sample}

The sample calculation required for the study was made using the G-POWER 3.1 Statistical Analysis Program. In this program, the sample size was calculated based on the non-parametric T-test with a significance level of 0.05 , power of $80 \%$ and a medium effect size of 0.50 and was determined as 128. The course of Professional Ethics is given as a 2-hour compulsory course per week in the 8th semester in the Geomatics Engineering Curriculum and aims to "make students gain written and verbal communication skills by evaluating the problems encountered in professional and ethical responsibility awareness on economic, political and legal grounds". In this context, the relevant lesson first makes 'theoretical evaluations on the basis of the basic approaches of engineering ethics' to the student; afterwards, it is performed in the form of 'opening the discussion of possible events that the student may encounter in his / her professional life by scripting'. The sample of the study composed 224 participants are aged 18 and over who are students in the Department of Geomatics Engineering of Konya Technical University "participating in the course of professional ethics during the semester, grasping universal ethical rules and values, learning the professional responsibility and ethical principles of engineering 
ethics and geomatics engineering, gaining the ability to question and evaluate professional dilemmas based on these and voluntarily participating in the study". The study was carried out between the dates 01.06.202018.07.2020.

\subsection{Data Collection Tools}

In the study, "Engineering Ethics Scale" was used to measure students' attitudes towards engineering ethics, and "Demographic Data Collection Form" was used to obtain personal information about students. The internet address of the data collection form was sent to the e-mail addresses of the students who accepted to participate in the study, and they were asked to fill in the form in digital environment.

Demographic Data Collection Form: This form was based on the literature and consists six questions. The questions in the form include the socio-demographic characteristics of the students (gender, age, high school from which they graduated, place of residence for the longest time, family type and socio-economic level).

Engineering Ethics Scale: The scale developed by İnam and Akdeniz (2020) consists of 21 items. Scale consists of two sub-dimensions: individual responsibilities (items 1-15, 20-21) and social responsibilities (items 16-19). This 21-item scale was scored according to the five-point Likert type: $1=$ Completely Ethical, 2 = Partially Ethical, 3 = Unsure, 4 = Partially Unethical, 5 = Completely Unethical. The total score that can be obtained on this scale varies between 21 and 105 points; It has been determined that as the score obtained from the scale increases, the positive attitude towards engineering ethics also increases. Items 9 , $16,17,18$, and 19 of the scale are scored reversely. The validity and reliability study of the scale was conducted by İnam and Akdeniz (2020), and the Cronbach Alpha value was 0.93, and the test-retest reliability was 0.86 . The Cronbach Alpha coefficient of the scale in this study was 0.88 , the explained variance ratio was 44.55 , the $\mathrm{KMO}$ value was 0.880 as a result of the $\mathrm{KMO}$ and Barlett test, and the Barlett value was 1886.934 .

\subsection{Data Analysis}

IBM SPSS Statistics 22.0 Program was used for the analysis of the research data. Number and percentage calculations were made in the analysis of descriptive data. Whether the data showed a normal distribution was examined using the Shapiro Wilk Test (Althouse et al., 1998). The null hypothesis to be established for this test is that the data series obtained from a sample belongs to a society with a normal distribution (Arslan et al., 2020). The value of test statistics results lies between zero and one. Small values of this test lead to the rejection of normality whereas a value of one indicates normality of the data (Razali and Wah, 2011). The Mann Whitney U test is used to compare differences of non-normally distributed parameters between groups when there are two groups in the comparison of quantitative data (Bildirici, 2014). In the study, the Mann Whitney $U$ test was used to determine whether the total score averages of the engineering ethics scale differ according to gender and age variables of the geomatics engineering students. Kruskal Wallis test is used to compare differences non-normally distributed parameters between groups when there are more than two groups in comparison of quantitative data (Vargha and Delaney, 1998). In the study, Kruskal Wallis test was used to determine whether the total score averages of the engineering ethics scale differ according to the variables of which high school type, the longest residence place, family type and socio-economic level. The origin of the difference between variables was determined by using Bonferroni-corrected Mann Whitney U Test (Eral and Vehid, 2013). In statistical analysis, the results were evaluated at $95 \%$ confidence interval and the level of significance was accepted as $\mathrm{p}<0.05$.

Research hypotheses;

$\mathrm{H}_{1}$ : There is a significant difference between the gender of the students and their attitude towards engineering ethics.

$\mathrm{H}_{2}$ : There is a significant difference between the students' age and their attitude to engineering ethics.

$\mathrm{H}_{3}$ : There is a significant difference between the type of high school students graduated from and their 
attitude towards engineering ethics.

$\mathrm{H}_{4}$ : There is a significant difference between the place where students reside for the longest time and their engineering ethics attitude.

$\mathrm{H}_{5}$ : There is a significant difference between students' family structure and engineering ethics.

$\mathrm{H}_{6}$ : There is a significant difference between the socio-economic status of students and their attitude to engineering ethics.

\section{RESULTS}

Results regarding the socio-demographic characteristics of the students participating in the study are shown in Table 1.

Table 1. Demographic Variables

\begin{tabular}{|c|c|c|}
\hline & Frequency (n) & Rate (\%) \\
\hline \multicolumn{3}{|l|}{ Gender } \\
\hline$\square$ Female & 82 & 36.6 \\
\hline$\square$ Male & 142 & 63.4 \\
\hline \multicolumn{3}{|l|}{ Age } \\
\hline$\square 21-30$ & 219 & 97.8 \\
\hline$\square 31$ and over & 5 & 2.2 \\
\hline \multicolumn{3}{|l|}{ High School Type } \\
\hline$\square$ Anatolian High School & 166 & 74.1 \\
\hline$\square$ Anatolian Religious Vocational High School & 7 & 3.1 \\
\hline$\square$ Science High School & 14 & 6.3 \\
\hline$\square$ Vocational and Technical Anatolian High School & 12 & 5.3 \\
\hline$\square$ Private High School & 25 & 11.2 \\
\hline \multicolumn{3}{|l|}{ The Longest Residence Place } \\
\hline$\square$ Village & 14 & 6.3 \\
\hline$\square$ Town & 5 & 2.2 \\
\hline$\square$ District & 66 & 29.4 \\
\hline$\square$ City & 139 & 62.1 \\
\hline \multicolumn{3}{|l|}{ Family Type } \\
\hline$\square$ Nuclear Family & 177 & 79.0 \\
\hline$\square$ Extended Family & 34 & 15.2 \\
\hline$\square$ Broken Family & 11 & 4.9 \\
\hline$\square$ Other & 2 & 0.9 \\
\hline \multicolumn{3}{|l|}{ Socio-economic Level } \\
\hline$\square$ Income less than Expense & 26 & 11.6 \\
\hline$\square$ Equal Income and Expense & 174 & 77.7 \\
\hline$\square$ Income more than Expense & 24 & 10.7 \\
\hline $\begin{array}{l}\text { TOTAL } \\
\end{array}$ & 224 & $\% 100$ \\
\hline
\end{tabular}

When Table 1 is examined, $63.4 \%$ of the students participating in the study are male students. The majority of the students participating in the survey (97.8\%) are between the ages of 21-30. Among the participants, the number of students who graduated from Anatolian High School the most $(74.1 \%)$ stands out. $62.1 \%$ of the students lived in the city centre, $29.4 \%$ in the district centre, $6.3 \%$ in the village and $2.2 \%$ in the town / town for the longest time. When the family structure of the students was examined, it was determined that $79 \%$ of them had nuclear family structure. It is seen that $77.7 \%$ of students' income levels are equal in income-expense balance.

Table 2 shows the minimum, maximum and average scores obtained by the geomatics engineering 
students participating in the study from the total and sub-dimensions of the engineering ethics scale.

Table 2. The mean scores of students regarding attitude levels to engineering ethics $(n=224)$

\begin{tabular}{|c|c|c|c|c|c|}
\hline & 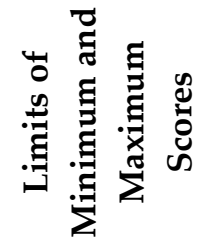 & 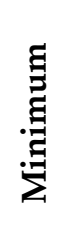 & 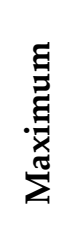 & 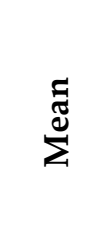 & 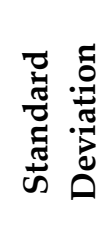 \\
\hline Engineering Ethics Scale (EES) & $21-105$ & 47 & 105 & 93.90 & 9.56 \\
\hline $\begin{array}{l}\text { Individual Responsibilities Sub- } \\
\text { Dimension }\end{array}$ & $17-85$ & 28 & 85 & 74.82 & 9.17 \\
\hline Social Responsibilities Sub-Dimension & $4-20$ & 12 & 20 & 19.08 & 1.37 \\
\hline
\end{tabular}

When Table 2 is examined, the total score average of the students in the engineering ethics scale was 93.90, the individual responsibilities sub-dimension average score average was 74.82 , and the social responsibilities sub-dimension mean score was found to be 19.08.

Table 3 shows the effects of the socio-demographic characteristics on attitudes of participants towards engineering ethics.

As Table 3 is examined, a statistically significant difference was found between the gender and age of geomatics engineering students and the total and individual responsibilities sub-dimension mean scores of the engineering ethics scale $(\mathrm{p}<0.005)$.

As a result of the Kruskal Wallis Test, where socio-demographic variables such as the high school where the students graduated, the longest residence, family structure and socio-economic status were analysed, there is no significant difference between the mean scores of the high school where the students graduated, the longest residence and family structure variables and engineering ethics attitude and individual responsibilities / social responsibilities sub-dimensions ( $p>0.05$ ). A statistically significant difference was found between the socio-economic status of the geomatics engineering department students and the engineering ethics scale total and individual responsibilities sub-dimension mean scores $(p<0.05)$. The measurement which the difference in the socio-economic status of the students originated was determined by using the Bonferroni Corrected Mann Whitney U Test. Since there are three pairs of comparisons in the analysis, the accepted significance level $(p=0.05)$ should be divided by three to determine the new level of significance. The new significance level is 0.016 . As a result of the engineering ethics scale test, a statistically significant difference was found according to the socio-economic status between students whose income is less than expenses and students whose income is equal to expenses ( $p$ $=0.007$ ). Similarly, as a result of the individual responsibilities sub-dimension test, a statistically significant difference was found according to the socio-economic status between students whose income is less than expenses and students whose income is equal to their expenses $(p=0.005)$. 
Table 3. The effect of students' socio-demographic characteristics on engineering ethics scale average scores

\begin{tabular}{|c|c|c|c|c|}
\hline \multicolumn{2}{|c|}{ Descriptive Features } & \multirow{2}{*}{$\begin{array}{c}\text { Engineering } \\
\text { Ethics Scale } \\
\text { (EES) }\end{array}$} & \multirow{2}{*}{$\begin{array}{c}\begin{array}{c}\text { Individual } \\
\text { Responsibilities } \\
\text { Sub-Dimension }\end{array} \\
76.90 \pm 8.00\end{array}$} & \multirow{2}{*}{$\begin{array}{c}\text { Social } \\
\text { Responsibilities } \\
\text { Sub-Dimension }\end{array}$} \\
\hline \multirow{4}{*}{ 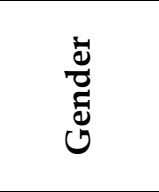 } & Female & & & \\
\hline & Male & $92.57 \pm 10.09$ & $73.62 \pm 9.60$ & $18.95 \pm 1.53$ \\
\hline & $\mathbf{U}$ & 4074.000 & 4087.000 & 5236.000 \\
\hline & $\mathbf{p}$ & $0.000^{*}$ & $0.000^{*}$ & 0.166 \\
\hline \multirow{4}{*}{$\stackrel{\infty}{4}$} & $21-30$ & $93.73 \pm 9.60$ & $74.66 \pm 9.20$ & $19.07 \pm 1.38$ \\
\hline & 30 and over & $101.40 \pm 2.30$ & $82.00 \pm 2.00$ & $19.40 \pm 0.89$ \\
\hline & $\mathrm{U}$ & 161.000 & 148.000 & 501.000 \\
\hline & p & $0.007^{*}$ & $0.005^{*}$ & 0.720 \\
\hline \multirow{8}{*}{ 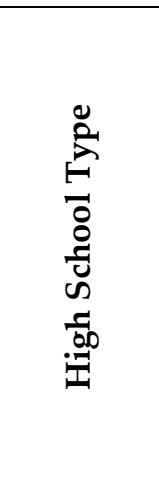 } & Science High School & $92.29 \pm 7.25$ & $74.35 \pm 5.77$ & $17.93 \pm 2.27$ \\
\hline & Anatolian High School & $94.17 \pm 9.61$ & $75.07 \pm 9.19$ & $19.10 \pm 1.26$ \\
\hline & $\begin{array}{l}\text { Vocational and Technical } \\
\text { Anatolian High School }\end{array}$ & $89.08 \pm 13.19$ & $69.50 \pm 13.31$ & $19.58 \pm 0.67$ \\
\hline & $\begin{array}{l}\text { Anatolian Religious } \\
\text { Vocational High School }\end{array}$ & $95.85 \pm 3.34$ & $76.86 \pm 3.18$ & $19.00 \pm 1.29$ \\
\hline & Private High School & $94.72 \pm 9.42$ & $75.40 \pm 9.11$ & $19.32 \pm 1.49$ \\
\hline & $X^{2} \mathrm{KW}$ & 6.187 & 5.918 & 9.023 \\
\hline & df & 4 & 4 & 4 \\
\hline & $\mathrm{p}$ & 0.186 & 0.205 & 0.061 \\
\hline \multirow{7}{*}{ 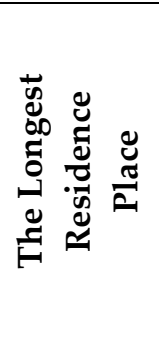 } & Village & $92.07 \pm 10.31$ & $72.85 \pm 10.44$ & $19.21 \pm 0.89$ \\
\hline & Town & $86.20 \pm 17.66$ & $66.20 \pm 17.66$ & $20.00 \pm 1.00$ \\
\hline & Distrrict & $95.32 \pm 5.88$ & $76.27 \pm 5.38$ & $19.05 \pm 1.32$ \\
\hline & City & $93.68 \pm 10.43$ & $74.64 \pm 9.94$ & $19.04 \pm 1.45$ \\
\hline & $\mathrm{X}^{2} \mathrm{KW}$ & 2.399 & 3.191 & 3.783 \\
\hline & df & 3 & 3 & 3 \\
\hline & $\mathrm{p}$ & 0.494 & 0.363 & 0.286 \\
\hline \multirow{7}{*}{ 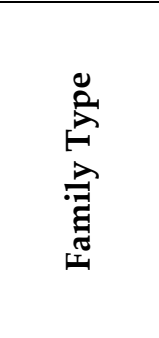 } & Nuclear Family & $94.03 \pm 9.33$ & $74.97 \pm 8.89$ & $19.06 \pm 1.39$ \\
\hline & Extended Family & $93.47 \pm 11.59$ & $74.15 \pm 11.44$ & $19.32 \pm 1.07$ \\
\hline & Broken Family & $94.09 \pm 7.34$ & $75.45 \pm 6.35$ & $18.64 \pm 1.86$ \\
\hline & Other & $88.50 \pm 4.95$ & $69.50 \pm 6.36$ & $19.00 \pm 1.41$ \\
\hline & $\mathrm{X}^{2} \mathrm{KW}$ & 2.524 & 2.293 & 1.437 \\
\hline & df & 3 & 3 & 3 \\
\hline & $\mathbf{p}$ & 0.471 & 0.514 & 0.697 \\
\hline \multirow{6}{*}{ 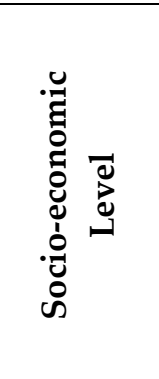 } & Income less than expense & $90.31 \pm 11.37$ & $71.38 \pm 10.70$ & $18.92 \pm 1.41$ \\
\hline & $\begin{array}{l}\text { Equal Income and } \\
\text { Expense }\end{array}$ & $94.34 \pm 9.76$ & $75.88 \pm 9.39$ & $19.05 \pm 1.43$ \\
\hline & $\begin{array}{l}\text { Income more than } \\
\text { Expense }\end{array}$ & $94.58 \pm 3.63$ & $75.12 \pm 3.57$ & $19.45 \pm 0.78$ \\
\hline & $\mathbf{X}^{2} \mathrm{KW}$ & 8.896 & 10.017 & 1.330 \\
\hline & df & 2 & 2 & 2 \\
\hline & $\mathrm{p}$ & $0.012^{*}$ & $0.007^{*}$ & 0.514 \\
\hline
\end{tabular}

U: mann whitney $u$ test; $X^{2}{ }^{2}$ : kruskal wallis chi-square; $d f$ : degree of freedom; $p<0.05$ 


\section{DISCUSSION}

This study puts forth the engineering ethics attitude levels and effect of socio-demographic variables on this attitude of the geomatics engineering students who take professional ethics course. When the mean scores of the students participating in the study are examined; It was determined that the students' level of participation in judgments towards engineering ethics attitude was high (Average $=93.90$ ).

H1: When the hypothesis "There is a significant difference between the gender of the students and their attitude to engineering ethics" was tested, a statistically significant difference was found $(p<0.05)$. In this case, the $\mathrm{H} 1$ hypothesis is accepted. It has been observed that female participants in the survey are more sensitive than male students in terms of professional life and social value judgments. When the literature is examined, it is emphasized that women have higher ethical attitudes than men (Poorsoltan et al., 1991; Borkowski and Ugras, 1992; Ruegger and King, 1992; Galbraith and Stephenson, 1993; Knotts et al., 2000, West et al., (2004)). In another study Cohen et al., (1998), It has been found that there is a significant relationship between gender and ethical decision-making skills that women are more sensitive to ethical issues than men (cited in Özyer and Azizoğlu, 2010). In a study by Daştan (2009), it was found that female participants were more tend to engaging in ethical behaviour, and there was a significant relationship between gender and ethical decisions. In different studies conducted by Güney (2018), Üzüm and Sivrikaya (2018), it was found that there is a significant difference between gender and ethical values in favour of female students. In this context, the H1 hypothesis analysis result is in line with the other research results.

H2: The hypothesis "There is a significant difference between the students' age and their attitude on engineering ethics" was found to be statistically significant $(\mathrm{p}<0.05)$ and the $\mathrm{H}_{2}$ hypothesis was accepted. The students at the age of 30 and over participating in the research were more conscious and more mature / selective in their value judgments, and it has been determined that they give priority to engineering ethics values. This situation is thought to be due to the more objective approaches of adults aged 30 and over to life and expectations compared to younger people. As a matter of fact, when the literature is reviewed, it is pointed out that there is a positive relationship between age and ethical attitude. According to Serwinek (1992), Dawson (1997) and Fritzche (1997), age has an absolute effect on a person's ethical attitude. Longenecker et al. (1989) found that young people can be more arbitrary on ethical issues. Çobanoğlu et al. (2005) and Ural (2003) revealed that age factor positively affects behaviour and in accordance with ethical principles and older people tend to behave ethically more. Adkins and Radtke (2004) found that older students at schools approach things more ethically than younger ones.

$\mathrm{H}_{3}$ : "There is a significant difference between the type of high school the students graduated from and the attitude of engineering ethics" was not found statistically significant ( $\mathrm{p}>0.05)$ and the $\mathrm{H}_{3}$ hypothesis was rejected. Since the students who participated in the survey graduated from secondary education institutions (Science High School / Anatolian High School / Private High School) with an education standard above the average and reached the university with a certain social basic values saturation, the total score average of engineering ethics was close. In the study conducted by Akkaya (2016) using "accounting professional ethics scale", no significant difference was found between the type of high school students graduated from and their perceptions of professional ethics.

$\mathrm{H}_{4}$ : The hypothesis "There is a significant difference between the place of residence of the students for the longest time and the attitude of engineering ethics" was not found statistically significant ( $>0.05)$ and the $\mathrm{H}_{4}$ hypothesis was rejected. It has been determined that the place of residence is not an important factor in professional ethics and social life sensitivities, and that the person approaches ethical values within their vital principles. According to the studies conducted by Üzüm and Sivrikaya (2018) and Alkan (2015), no significant difference was found between students' level of inclination towards ethical values and their residence status. In another study by Sakar and Aybek (2018), it was observed that students' perceptions of their ethical rights and responsibilities did not differ significantly according to the place of residence.

$\mathrm{H}_{5}$ : When the hypothesis "There is a significant difference between the students' family structure and engineering ethics" hypothesis was tested, no statistically significant difference was found ( $>>0.05)$ and the $\mathrm{H}_{5}$ hypothesis was rejected. Although it is generally accepted that students who grow up in a regular 
family environment will be more sensitive in their approach to engineering ethics, It has been determined that the students have an awareness of their expectations from the engineering profession and "the more they adhere to ethical values, the higher their success and motivation will increase". As a matter of fact, in a study conducted by Aykan et al. (2019), no statistically significant difference was found between students' family types and their ethical sensitivity. However, in the study conducted by Küçük et al. (2017), it was found that the family structure made a significant difference in the ethical decision-making levels of the students, and it was determined that the students with nuclear family structure had higher mean scores.

$\mathrm{H}_{6}$ : The hypothesis "There is a significant difference between the socio-economic status of the students and their attitude on engineering ethics" was found significant $(\mathrm{p}<0.05)$ and the $\mathrm{H}_{6}$ hypothesis was accepted. As a result of the advanced analysis, it was determined that the difference between the groups was "caused by the students whose income is less than the expense". In the analysis of socio-economic variables, although it is seen that students generally believe in the principles and necessity of engineering ethics, it has been accepted that students whose income is equal to or more than expenses exhibit more comfortable / selfconfident behaviour in the social life process is also accepted in the engineering ethics approach. In the literature, it is emphasized that low economic level may affect ethical attitude negatively. As a matter of fact, in the study conducted by Çavuşoğlu and Kutluk (2016), a significant difference was detected between students' perceptions of accounting professional ethics and their income levels, and it was observed that 'students with higher income have stronger values in ethical behaviour'. Çınar ve Güney (2012) concluded that adherence to professional ethical principles increases in direct proportion to income level. Kutlu (2008) concluded that 'employees with lower monthly income experience more ethical dilemmas in their professional lives'.

\section{CONCLUSION}

It is considered that students who graduate from the undergraduate geomatics engineering department will work together with other related disciplines in the public and private sector, on technical infrastructure and superstructure, geodetic measurement and location determination processes, topographic and thematic map production, spatial database formation and Geographic Information System (GIS) applications, urban and rural area design, cadastre / land development / expropriation / real estate valuation, it is very important for these students to acquire behavioural maturity towards engineering ethics and the ability to evaluate-questioning from different perspectives through education. As a requirement of this, the professional / engineering ethics course is put as a compulsory course in the last semester of the curriculum in the geomatics engineering departments by the Council of Higher Education. Although the achievements of the professional ethics course are important for all professional disciplines, it has a particular importance due to the nature and working conditions of the geomatics engineering profession. Because a geomatics engineer has interactive responsibilities in technical, economic and sociological issues to the society and the natural environment, managers, employers, customers and colleagues. For this reason, geomatics engineering students education as individuals with high ethical awareness through education in the undergraduate education process, will increase the quality of the geomatics engineering profession and the sense of belonging / ownership among its members and will enable the training of qualified professionals and will be the guarantee of the reputation of engineers.

This study, within this significance, has applied to a university geomatics engineering department students in Turkey to evaluate acquisitions for the future from the current situation of the students and to determine the effect of students' socio-demographic variables on engineering ethics. According to the findings, it is thought that the results may differ if this research is applied to students studying in the geomatics engineering department of different countries / societies of different universities. In addition, in order to develop this study, it is recommended to make a comparison and demonstrate the effectiveness of the results by applying it on different population characteristics on university students who take and do not take the course of professional ethics. 


\section{LIMITATIONS}

This limitation of the study is an implementation on geomatics engineering students in a state university in a specific region in Turkey.

Ethics approval: Approval was obtained from The Scientific Research and Publication Ethics Committee of Konya Technical University (Approval Number: 2020-04/01). The procedures used in this study adhere to the tenets of the Declaration of Helsinki.

\section{REFERENCES}

Accreditation Board for Engineering and Technology (ABET), 2005, "Criteria for accrediting engineering programs", ABET Inc, USA, https://www.abet.org/, ziyaret tarihi: 08.09.2020.

Adkins, N., Radtke R.R., 2004, “Students' and faculty Members' perceptions of the importance of business ethics and accounting ethics education: Is there an expectations gap?", Journal of Business Ethics, 51(3), 279-300.

Akkaya, G., 2016, “Muhasebe mesleğinde meslek etiği: Meslek yüksekokullarında muhasebe dersi alan öğrenciler tarafından algılanması üzerine bir araştırma", V. Uluslararası Meslek Yüksekokulları Seтроzуити, Prizren, 18-20 Mayıs 2016.

Alkan, G.İ., 2015, “Muhasebe eğitiminde etik: Ön lisans öğrencilerinin etik algılarına yönelik bir araştırma", Business and Economics Research Journal, 6(2), 113-125.

Althouse, L.A., Ware, W.B., Ferron, J.M., 1998, “Detecting departures from normality: A Monte Carlo simulation of a new omnibus test based on moments", Paper presented at the Annual Meeting of the American Educational Research Association, San Diego/ABD.

Ameen, E.C., Guffey, D.M., McMillan, J.J., 1996, “Gender differences in determining the ethical sensitivity of future accounting professionals", Journal of Business Ethics, 15(5), 591-597.

Arslan, A.K., Tunç, Z., Çolak, C., 2020, “Normal dağılıma uygunluğu değerlendirmek için açık kaynak web tabanlı yazılım: normal dağılımı inceleme yazılımı", Fırat Tip Dergisi, 25(2).

Aykan, E.B., Fïdancı, B.E., Yıldız, D., 2019, “Hemşirelik öğrencilerinde ahlaki olgunluk ve etik duyarlılığın değerlendirilmesi", Sağlık Bilimleri Üniversitesi Hemşirelik Dergisi, 1(2), 84-91.

Bildirici, F., 2014, "Özel eğitime gereksinimi olan çocuğa sahip ailelerde aile yükü ile psikolojik dayanıklılık arasındaki ilişki, Yüksek Lisans Tezi, Haliç Üniversitesi, Sosyal Bilimler Enstitüsü, İstanbul.

Borkowski S.C., Ugras, Y.J., 1992, "The ethical attitudes of students as a function of age, sex and experience", Journal of Business Ethics, 11(12), 961-979.

Cohen, J.R., Pant, L.W., Sharp, D.J., 1998, "The effect of gender and academic discipline diversity on the ethical evaluations, ethical intentions and ethical orientation of potential public accounting recruits", Accounting Horizons, 12(3), 250-270.

Colby, A., Sullivan, W.M., 2008, "Ethics teaching in undergraduate engineering education", Journal of Engineering Education, 97(3), 327-338.

Çavuşoğlu, K., Kutluk, F., 2016, “Meslek yüksekokulunda muhasebe dersi alan öğrencilerin muhasebe etiğine bakış açılarının tespitine yönelik bir araştırma: Anamur MYO örneği", Uluslararası Alanya İşletme Fakültesi Dergisi, 8(2), 109-120.

Çınar, O., Güney, S., 2012, "Serbest muhasebeci mali müşavirlerin (SMMM) etik algıları: Erzurum örneği”, Atatürk Üniversitesi İktisadi ve İdari Bilimler Dergisi, 26(2), 91-106.

Çobanoglu, N., Haberal B., Çaglar, S., 2005, “Tıbbi arastırma ve yayın konusunda etik duyarlılık araştırması", Türk Tıp Dizini, Saglık Bilimlerinde Süreli Yayıncılık, 101-130.

Daştan, A., 2009, "Etik eğitiminin muhasebe eğitimindeki yeri ve önemi: Türkiye değerlendirilmesi", Marmara Üniversitesi Iktisadi ve İdari Bilimler Dergisi, 26(1), 281-311.

Dawson, M.L., 1997, "Ethical differences between men and women in the sales profession", Journal of Business Ethics, 16(11), 1143-1152.

Deniz, R., İpbüker, C., Göksel, Ç., 2005, "Mühendislik etiği dersi niçin zorunlu olarak okutulmalıdır?", 
TMMOB Harita ve Kadastro Mühendisleri Odası, 10. Türkiye Harita Bilimsel ve Teknik Kurultayı, Ankara, 28 Mart-1 Nisan 2005.

Eral, G., Vehid, H.E., 2013, “Nicel verilerin yer aldığı bağımsız ve bağımlı gruplarda uygulanan istatistiksel yöntemler, Çocuk Dergisi, 13(4), 138-140.

Eroğlu, M., Göksel, Ç., Güney C., 2019, "Yeni kavramlar, yeni teknolojiler ve mühendislik etiği 2.0”, TMМОВ Harita ve Kadastro Mühendisleri Odası, 17. Türkiye Harita Bilimsel ve Teknik Kurultayı, Ankara, 25-27 Nisan 2019.

Fritzche, D.J., 1997, "Business ethics: a global and managerial perspective”, McGraw Hill International Editions, Boston/ABD.

Galbraith, S., Stephenson, H.B., 1993, "Decision rules used by male and female business students in making ethical value judgement: another look", Journal of Business Ethics, 12(3), 227-233.

Gençoğlu, T.M., 2008, "Mühendislikte etik", TMMOB Elektrik Mühendisleri Odası Ankara Şubesi Haber Bülten, 5(1), 26-31.

Griggs Jr, F.E., 1997, “To be or not to be-ethical that is!..", Journal of Professional Issues in Engineering Education and Practice, 123(2), 82-89.

Güney, C., 2018, “Muhasebe meslek mensubu adaylarının mesleki etik algısı üzerine bir araştırma:Gazanfer Bilge Meslek Yüksekokulu örneği", Elektronik Sosyal Bilimler Dergisi, 17(65), 295-316.

İnam, Ş., Akdenïz, H.B., 2020, “Harita mühendisleri özelinde mühendislik etiği ölçeğinin geçerlilik ve güvenirlik analizi üzerine bir çalışma", Selçuk Üniversitesi Fen Fakültesi Fen Dergisi, 46(1), 13-28.

İnayet, A., 2002, "Yönetsel Mesleki ve Örgütsel Etik", Pegem A Yayıncllık, 3.Baskı, İstanbul/Türkiye.

International Federation of Surveyors (FIG), 2002, "Mutual Recognition of Professional Qualifications", FİG Publications, Frederiksberg/Denmark.

Knotts, T.L., Lopes, T.B., Mesak, H.I., 2000, “Ethical judgements of college students: an empirical analysis", Journal of Education for Business, 75(3), 158-163.

Kutlu, H., 2008, “Muhasebe Meslek Mensupları ve çalışanlarının etik ikilemleri: Kars ve Erzurum illerinde bir araştırma", Ankara Üniversitesi SBF Dergisi, 63(2), 143-170.

Küçük, S., Uysal, N., Çakırer Çalbayram, N., Kahriman, İ., Altundağ, S., Gönenç, İ., 2017, “Hemşirelik öğrencilerinin etik karar verme düzeyleri ve etkileyen faktörlerin belirlenmesi", ACU Sağllk Bilimleri Dergisi, 157-162.

Longenecker, J.G., McKinney, J.A., Moore, C.W., 1989, “Egoism and independence: entrepreneurial ethics", Organizational Dynamics, 16(3), 64-72.

Milli Eğitim Bakanlı̆̆ı, 2006, "Meslek etiği", MEGEP (Mesleki Eğitim ve Öğretim Sisteminin Güçlendirilmesi Projesi), Ankara/Türkiye.

National Society of Professional Engineers, 1977, "Code of ethics for engineers", https://www.nspe.org/resources/ethics/code-ethics, ziyaret tarihi: 31.10.2021.

Özyer, K., Azizoğlu, Ö., 2010, "Demografik değişkenlerin kişilerin etik tutumları üzerindeki etkileri”, Ekonomik ve Sosyal Araştırmalar Dergisi, 6(2), 59-84.

Pieper, A., 1999, "Etiğe giriş", Çevirmen: Veysel Atayman, Gönül Sezer, Ayrıntı Yayınları, İstanbul/Türkiye.

Poorsoltan, K., Amin, S.G., Tootonchi, A., 1991, "Business ethics: views of future leaders", SAM Advanced Management Journal, 56(1), 4-9.

Razali, N.M., Wah, Y.B., 2011, "Power comparisons of shapiro-wilk, kolmogorov-smirnov, lilliefors and anderson-darling tests", Journal of Statistical Modeling and Analytics, 2(1), 21-33.

Ruegger, D., King, E.W., 1992, "A study of the effect of age and gender upon student business ethics", Journal of Business Ethics, 11(3), 179-186.

Sakar, N., Aybek, B., 2018, "Lise öğrencilerinin etik hak ve sorumluluklarına ilişkin algılarının çeşitli değişkenlere göre incelenmesi", Scientific Educational Studies, 2(2), 111-128.

Serwinek, P.J., 1992, "Demographics and related in ethical views among small businesses", Journal of Bioethics, 11, 555-566. 
Taluğ, C., Kanber, H., Yalım Y., 2015, “Türkiye'de mühendislik eğitimi”, Türkiye BiyoetikDergisi, 2(3), 202 212.

Ural, T., 2003, "İ̧letme ve pazarlama etiğ i”, Detay Yayıncılık, Ankara/Türkiye.

Üzüm, B., Özkurt Sïvrikaya, S., 2018, “Meslek yüksekokulu öğrencilerinin etik değerlere yatkınlık düzeyleri (Kocaeliİ MYO örneği)", Uluslararası Bilimsel Araştırmalar Dergisi (IBAD), 3(1), 230-240.

Vargha, A., Delaney, H.D., 1998, "The Kruskal Wallis test and stochastic homogeneity", Journal of Educational and Behavioral Statistics, 23(2), 170-192.

West, T., Ravenscroft, S.P., Shrader, C.B., 2004, “Cheating and moral judgment in the college classroom: a natural experiment", Journal of Business Ethics, 54(2), 173-183. 